\title{
Pelatihan Kewirausahaan Pemanfaatan Limbah Kulit Mangga Menjadi Cemilan Keripik Aneka Rasa Sebagai Upaya Diversifikasi Olahan Pangan Yang Sehat Dan Kaya Manfaat
}

\author{
Fitriana, Orisanto Darma Setiawan \\ Universitas Muhammadiyah Jember; Jl. Karimata 49 Jember \\ e-mail: fitriana@unmuhjember.ac.id, orisantodarmasetiawan@gmail.com
}

Diterima: Februari 2021 | Dipublikasikan: Juni 2021

\begin{abstract}
ABSTRAK
Pada umumnya, bagian dari buah mangga yang banyak dikonsumsi adalah daging buahnya sedangkan kulitnya dibuang dan menjadi limbah. Padahal kulit buah mangga juga mengadung banyak senyawa yang bermanfaat bagi tubuh manusia. Hal tersebut memunculkan ide untuk melakukan pengolahan kulit buah mangga menjadi camilan yang sehat dan kaya manfaat. Sasaran atau mitra kegiatan ini adalah ibu-ibu rumah tangga istri karyawan UD. Barokah yang berlokasi di RT.02 RW.01, Kampung Bukkolan, Desa Paowan/Kecamatan Panarukan, Kabupaten Situbondo, Provinsi Jawa Timur. Permasalahan yang dihadapi mitra yaitu: 1) Mitra belum memiliki pengetahuan dan keterampilan membuat produk olahan limbah kulit mangga. 2) Mitra belum mengetahui cara promosi dan pemasaran dari produk keripik sebagai produk olahan limbah kulit mangga. 3) Mitra belum mengetahui manajemen keuangan dalam melakukan penjualan. Berdasarkan identifikasi permasalahan yang terjadi pada mitra, maka diperlukan adanya program nyata untuk mengatasi permasalahan tersebut. Program tersebut yaitu melakukan pembinaan terhadap mitra melalui kegiatan pelatihan dalam produksi, pengemasan, dan pemasaran secara online keripik kulit mangga serta pelatihan manajemen keuangan.
\end{abstract}

Kata Kunci: kewirausahaan, kulit mangga, keripik aneka rasa, diversifikasi olahan pangan

\section{ABSTRACT}

In general, the part of the mango fruit that is mostly consumed is the pulp, while the skin is removed and becomes waste. Even though mango rind also contains many compounds that are beneficial to the human body. This led to the idea of processing mango rind into healthy and beneficial snacks. The targets or partners of this activity are housewives of UD Barokah employees which is located at RT.02 RW.01, Bukkolan Village, Paowan Village/Panarukan District, Situbondo Regency, East Java Province. The problems faced by partners are: 1) Partners do not have the knowledge and skills to make mango rind become chips, 2) Partners do not know how to promote and market the chips, and 3) Partners do not know financial management in making sales. Based on the identification of problems that occur with partners, it is necessary to have a real program to overcome these problems. The program is to provide guidance to partners through training activities in the production, packaging and online marketing of mango rind chips as well as financial management training.

Keywords: Entrepreneurship, Mango Rind, Various Flavor Chip Snacks, Diversification of Food Processed

\section{PENDAHULUAN}

UD. Barokah adalah home industry yang bergerak dalam pembuatan tahu yang didirikan pada tahun 1991 oleh Bapak H. Imam Buchari. UD. Barokah berlokasi di RT.02 RW.01 Kampung Bukkolan Desa Paowan/Kecamatan Panarukan Kabupaten Situbondo Provinsi Jawa Timur. Istriistri dari para karyawan UD. Barokah berusia antara 25-40 tahun dimana usia tersebut merupakan usia produktif sehingga masih dimungkinkan untuk melakukan berbagai hal untuk membantu suami dalam meningkatkan kesejahteraan keluarga. Namun kenyataannya, sebagian besar kelompok usia produktif tersebut berprofesi sebagai ibu rumah tangga yang hanya mengandalkan penghasilan sang suami untuk memenuhi kehidupan sehari-hari karena tidak memiliki penghasilan 
tetap sendiri. Hanya salah satu yang bekerja (kebanyakan suami), istri lebih sering mengurus rumah tangga dan banyak memiliki waktu luang di rumah. Di sisi lain, kebanyakan mereka berpendidikan minimal SMA/sederajat dan belum dapat memberikan sumbangan pendapatan bagi keluarganya, karena kurangnya keterampilan dan informasi serta peluang usaha untuk meningkatkan pendapatan. Oleh karena itu, kegiatan ini diharapkan dapat memberi tambahan keterampilan sehingga dapat meningkatkan kesejahteraan keluarga.

Mangga (Mangifera indica L.) merupakan salah satu tanaman buah yang disukai masyarakat Indonesia. Buah ini dapat tumbuh dengan baik di daerah tropis maupun subtropis termasuk di Indonesia. Buah ini memiliki rasa manis dan menyegarkan. Buah mangga banyak mengandung mineral, vitamin $\mathrm{C}$, dan nutrisi pelengkap memiliki khasiat yang baik untuk kesehatan. Namun tidak hanya daging buahnya yang memiliki manfaat,tetapi kulitnya juga memiliki manfaat yang banyak seperti melancarkan peredaran darah, meremajakan kulit, menurunkan berat badan, obat cacing untuk anak, menghilangkan jerawat, dan mengatasi pendarahan yang berlebih selama haid (Halik et al., 2019). Selain itu, kulit mangga juga mengandung senyawa flavonoid yang dapat berfungsi sebagai antioksidan dan antibakteri (Kumar \& Pandey, 2013). Hasil penelitian menunjukkan bahwa senyawa flavonoid yang terkandung pada kulit buah mangga jumlahnya tiga kali lipat lebih tinggi dibandingkan yang terkandung pada daging buah mangga (Kim et al., 2010). Mangga yang sudah matang akan berbau harum khas dan warnanya akan menguning kemerahan. Jika ditekan, buah mangga yang sudah matang akan lebih empuk dibandingkan buah mangga yang masih mentah. Rasa daging buah mangga sangat manis dan segar. Di Kampung Bukkolan Desa Paowan memiliki potensi mangga yang melimpah. Masyarakat hanya menjual atau memakannya langsung tanpa diolah maka dari itu sangat diperlukan pelatihan kewirausahaan untuk memanfaatkan potensi mangga.

Pada umumnya, bagian dari buah mangga yang banyak dikonsumsi adalah daging buahnya sedangkan kulitnya dibuang dan menjadi limbah. Padahal kulit buah mangga masih bisa diolah menjadi produk yang memiliki nilai ekonomi. Kulit mangga dapat diolah menjadi keripik yang enak dan bermanfaat bagi kesehatan. Kandungan gizi yang terdapat pada kulit buah mangga dapat menjadi nilai jual tersendiri. Usaha keripik kulit mangga dapat menjadi peluang usaha yang berpotensi tinggi karena masih jarang yang mengusahakan produk dari olahan kulit manga (Mukti et al., 2017).

Proses pengolahan kulit mangga akan menghasilkan nilai tambah produk akibat meningkatnya nilai guna limbah kulit mangga. Nilai tambah merupakan pertambahan nilai suatu komoditas karena mengalami proses pengolahan, pengangkutan ataupun penyimpanan dalam suatu produksi (Saragih, 2004). Bagian lain dari buah mangga yang berupa kulit dan biji biasanya dibuang begitu saja. Padahal limbah dari buah mangga terutama bagian kulit masih dapat diolah menjadi aneka makanan, salah satunya adalah keripik. Hal inilah yang memotivasi mitra untuk memanfaatkan peluang bisnis produk olahan kulit mangga. Harapannya adalah menghasilkan pendapatan tambahan bagi ibu rumah tangga sekaligus juga berkontribusi mengurangi beban lingkungan dengan memanfaatkan limbah kulit mangga.

Berdasarkan analisis situasi diatas, maka dapat dirumuskan beberapa permasalahan yang dihadapi mitra terkait dengan pengolahan kulit limbah mangga, diantaranya adalah:

1. Mitra belum memiliki pengetahuan dan keterampilan membuat produk olahan limbah kulit mangga.

2. Mitra belum mengetahui cara promosi dan pemasaran dari produk keripik sebagai produk olahan limbah kulit mangga.

3. Mitra belum mengetahui manajemen keuangan dalam melakukan pemasaran.

Program pengabdian kepada masyarakat ini mempunyai tujuan, yaitu memberikan pengetahuan ketrampilan kepada masyarakat bahwa kulit manga yang selama ini menjadi penghuni tempat sampah tapi ternyata dapat diolah menjadi cemilan yang enak, sehat dan kaya manfaat. Pembuatan keripik mangga sebagai upaya diversifikasi olahan pangan untuk memanfaatkan kulit manga yang selama ini menjadi limbah. Selain itu, untuk meningkatkan kapasitas produksi dan nilai ekonomi produk serta sistem pemasarannya. Berdasarkan permasalahan mitra yang telah diuraikan pada bab sebelumnya, maka diperlukan adanya solusi yang nyata untuk mengatasi permasalahan tersebut. Solusi pertama yang ditawarkan dalam kegiatan pengabdian kepada masyarakat ini adalah melakukan penyuluhan dan pelatihan dalam melakukan pengolahan kulit mangga menjadi keripik. Solusi kedua yaitu setelah dilakukan pengolahan kulit mangga menjadi keripik, dilakukan pelatihan dalam melakukan pengemasan dan pelatihan strategi pemasaran secara online. Solusi Ketiga yaitu memberikan pelatihan tata cara pembukuan sederhana dalam melakukan kegitan penjualan. 


\section{METODE PELAKSANAAN}

\section{A. Tahapan Kegiatan}

Program Pengabdian Kepada Masyarakat ini dilaksanakan dengan cara menjalin kerjasama antara Tim Pengusul dengan mitra. Berdasarkan solusi permasalahan yang ditawarkan oleh pengusul, maka perlu diuraikan tahapan dalam melaksanakan solusi tersebut. Kegiatan Pengabdian ini akan dilaksanakan dalam tiga tahapan yaitu tahap perencanaan, tahap pelaksanaan, dan tahap evaluasi.

\section{Tahap Perencanaan Kegiatan}

Agar program ini berjalan secara maksimal, maka diperlukan perencanaan secara tepat, diantaranya yaitu:

a. Mengamati pentingnya mengadakan program untuk meningkatkan nilai tambah kulit mangga menjadi cemilan keripik yang enak renyah sehat dan kaya manfaat.

b. Melakukan survey ke lokasi mitra sekaligus meminta izin kerjasama kepada pemilik industri tahu UD. Barokah.

c. Menyusun waktu dan merencanakan tempat pelaksanaan kegiatan dengan mitra.

\section{Tahap Pelaksanaan Kegiatan}

Pelaksanaan kegiatan pengabdian ini dilakukan dalam tiga tahapan yaitu penyuluhan, pelatihan, pendampingan manajemen pemasaran dan keuangan, dan evaluasi. Berikut uraian tahapan dalam melaksanakan kegiatan tersebut:

Tabel 1. Tahapan Pelaksanaan Kegiatan

\begin{tabular}{|c|c|c|}
\hline Kegiatan & Tujuan & Tahapan \\
\hline Penyuluhan & $\begin{array}{lr}\text { Memotivasi } & \text { dan } \\
\text { memberikan } & \\
\text { pengetahuan } & \text { kepada } \\
\text { mitra terkait } & \text { potensi } \\
\text { kulit mangga } & \text { untuk } \\
\text { dijadikan keripik } & \end{array}$ & $\begin{array}{l}\text { 1. Memberikan motivasi kepada mitra untuk } \\
\text { mengikuti kegiatan yang berkaitan dengan } \\
\text { pengabdian pada masyarakat ini } \\
\text { 2. Memberikan penyuluhan proses pembuatan } \\
\text { keripik kulit mangga aneka rasa }\end{array}$ \\
\hline $\begin{array}{l}\text { Pelatihan } \\
\text { pembuatan } \\
\text { keripik kulit } \\
\text { mangga }\end{array}$ & $\begin{array}{l}\text { Memberikan } \\
\text { Pengetahuan dan } \\
\text { Keterampilan dalam } \\
\text { pembuatan keripik kulit } \\
\text { mangga }\end{array}$ & $\begin{array}{l}\text { 1. Mempersiapkan alat dan bahan untuk pembuatan } \\
\text { keripik kulit manga. } \\
\text { 2. Mengadakan pelatihan penggunaan mesin spinner } \\
\text { minyak. Mesin tersebut berfungsi untuk } \\
\text { mengurangi kadar minyak setelah penggorengan. } \\
\text { 3. Mengadakan pelatihan pembuatan keripik kulit } \\
\text { mangga aneka rasa }\end{array}$ \\
\hline $\begin{array}{l}\text { Pelatihan } \\
\text { Manajemen } \\
\text { Pemasaran } \\
\text { dan } \\
\text { Keuangan }\end{array}$ & $\begin{array}{l}\text { Memberikan } \\
\text { Pengetahuan dan } \\
\text { Keterampilan dalam } \\
\text { melakukan pemasaran } \\
\text { keripik kulit manga dan } \\
\text { manajemen keuangan }\end{array}$ & $\begin{array}{l}\text { 1. Mengadakan pelatihan cara pengemasan dan } \\
\text { pelabelan produk keripik kulit mangga } \\
\text { 2. Melakukan pembuatan akun media sosial untuk } \\
\text { pemasaran. } \\
\text { 3. Mengadakan pelatihan penggunaan media sosial } \\
\text { untuk pemasaran. } \\
\text { 4. Mengadakan pelatihan pembukuan secara }\end{array}$ \\
\hline $\begin{array}{l}\text { Monitoring } \\
\text { dan } \\
\text { Evaluasi }\end{array}$ & $\begin{array}{l}\text { Mengetahui progress } \\
\text { kegiatan dan evaluasi. }\end{array}$ & $\begin{array}{l}\text { Pemantauan melalui komunikasi telepon dan sosial } \\
\text { media kemajuan dari produk cemilan keripik kulit } \\
\text { mangga }\end{array}$ \\
\hline
\end{tabular}

Tahap pelaksanaan kegiatan pengabdian kepada masyarakat akan direalisasikan dengan mekanisme sebagai berikut:

1) Aspek produksi inovasi cemilan keripik kulit mangga dalam kemasan (sosialisasi program dan praktik pembuatan inovasi cemilan keripik kulit mangga, dan teknik pengemasan untuk meningkatkan mutu dan harga jual dengan packing yang berkualitas); 
2) Aspek manajemen yaitu pembukuan sederhana pengembangan usaha pembuatan cemilan keripik kulit mangga dan pendampingan pemasaran produk);

3) Evaluasi peningkatan pengetahuan dan ketrampilan dari mitra.

Selain hal tersebut diatas, pada pelaksanaan program pendampingan akan melatih mitra tentang perancangan desain label yang akan dipasang pada kemasan cemilan keripik kulit mangga. Desain label berisi nama merk dan informasi mengenai kontak person produsen.

Pada program pendampingan ini mitra diberikan gambaran tentang pengembangan atau diversifikasi produk cemilan keripik kulit mangga. Pengembangan produk cemilan keripik kulit mangga ini bertujuan untuk melatih kreativitas mitra dalam menciptakan berbagai varian rasa produk. Selain itu dengan adanya diversifikasi produk maka akan memberikan alternatif pilihan produk sekaligus untuk mempertahankan sekaligus meningkatkan pemasaran produk.

\section{HASIL KEGIATAN}

Pelaksanaan kegiatan pengabdian kepada masyarakat dengan sasaran Kelompok Ibu-Ibu Rumah Tangga UD. Barokah di Kampung Bukkolan RT.02 RW.01 Desa Paowan/Kecamatan Panarukan Kabupaten Situbondo dihadiri oleh 9 orang peserta dan dilaksanakan selama dua hari yaitu pada tanggal 26 dan 27 Desember 2020 bertempat di UD. Barokah dengan susunan acara sebagai berikut:

Tabel 2. Susunan kegiatan pengabdian yang dilaksanakan pada hari Sabtu, 26 Desember 2020

\begin{tabular}{crl}
\hline No & Waktu & \\
\hline 1. & $09.00-09.30$ & Pembukaan \\
2. & $09.30-11.00$ & Penyuluhan pengolahan kulit manga menjadi keripik aneka rasa \\
& & \\
3. & $11.00-12.30$ & ISHOMA \\
4. & $12.30-15.00$ & Pelaksanaan pelatihan pengolahan kulit mangga menjadi keripik \\
& & \\
5. & $15.00-15.10$ & Penutup \\
\hline
\end{tabular}

Tabel 3. Susunan kegiatan pengabdian yang dilaksanakan pada hari Minggu, 27 Desember 2020

\begin{tabular}{cll}
\hline No & \multicolumn{1}{c}{ Waktu } & \multicolumn{1}{c}{ Materi } \\
\hline 1. & $09.00-09.30$ & Pembukaan \\
2. & $09.30-11.00$ & Pelatihan tentang pengemasan keripik kulit mangga \\
3. & $11.00-12.30$ & ISHOMA \\
4. & $12.30-14.00$ & Pelatihan peningkatan strategi pemasaran dengan Internet Marketing \\
5. & $14.00-15.30$ & Pelatihan manajemen keuangan \\
6. & $15.30-15.40$ & Penutup \\
\hline
\end{tabular}

\section{A. Kegiatan Penyuluhan}

Pelaksanaan kegiatan pengabdian pada hari Sabtu 26 Desember 2020 dimulai dengan memberikan penyuluhan kepada peserta. Penyuluhan dilakukan dengan memberikan materi tentang potensi kulit mangga untuk dijadikan keripik dan proses pembuatan keripik dari kulit mangga. Pada penyuluhan ini juga disampaikan bahwa apabila diolah dan dikembangkan dengan baik, keripik dari kulit mangga ini akan mampu meningkatkan perekonomian masyarakat karena dapat dijual. Selama penyuluhan, peserta terlihat antusias mendengarkan penjelasan yang diberikan. Kegiatan penyuluhan ini diharapkan dapat meningkatkan pengetahuan peserta dalam melakukan pengolahan kulit mangga menjadi keripik yang bernilai jual tinggi.

\section{B. Pelatihan Pembuatan Keripik Kulit Mangga}

Setelah penyuluhan, pelaksanaan kegiatan pengabdian pada hari Sabtu 26 Desember 2020 dilanjutkan dengan kegiatan pelatihan pembuatan keripik dari kulit manga. Pelatihan dilakukan dengan melakukan demonstrasi atau praktek secara langsung pembuatan keripik dari kulit mangga. 
Tim pelaksana pengabdian menyediakan alat dan bahan yang dibutuhkan untuk kegiatan pelatihan, selanjutnya peserta diajak ikut serta dalam melakukan praktek pembuatan keripik dari kulit mangga seperti mengupas mangga, merendam dan membersihkan kulit mangga, menimbang bahan, membuat adonan, dan menggoreng kulit mangga hingga menjadi keripik. Pada kegiatan ini, peserta juga diberi pelatihan dalam menggunakan mesin spinner berfungsi untuk mengurangi kadar minyak setelah penggorengan. Keripik kulit mangga yang berhasil dibuat oleh para peserta memiliki tiga varian rasa yaitu rasa original, rasa balado, dan rasa coklat. Peserta terlihat antusias dan aktif dalam mengikuti kegiatan pelatihan ini. Melalui kegiatan pelatihan ini diharapkan peserta dapat membuat keripik dari kulit mangga secara mandiri

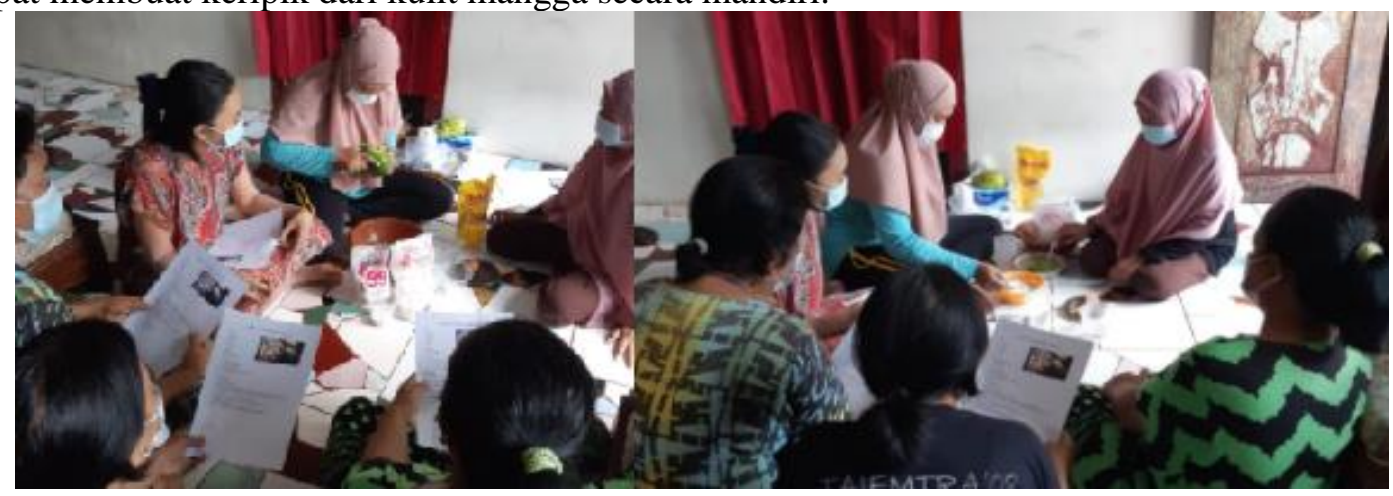

Gambar 1. Proses Pembuatan Keripik Kulit Mangga

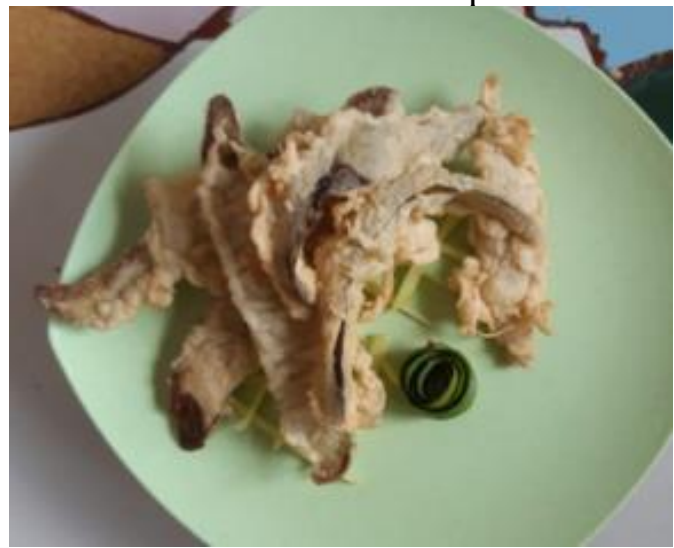

Gambar 2. Keripik Kulit Mangga Yang Dihasilkan Peserta

\section{Pelatihan Tentang Pengemasan Keripik Kulit Mangga}

Selain mengadakan pelatihan pembuatan keripik kulit mangga, tim pelaksana juga mengadakan pelatihan tentang pengemasan keripik kulit manggga yang dilaksanakan pada hari Minggu, 27 Desember 2020. Pada pelatihan pengemasan ini, pemateri memberikan pengetahuan kepada peserta tentang pentingnya pengemasan terhadap nilai jual suatu produk dan cara pengemasan yang baik dan benar yaitu pengemasan yang bersih dan terlihat menarik. Selanjutnya peserta diminta untuk mempraktikan cara pengemasan tersebut. Para peserta juga terlihat antusias dalam mengikuti kegiatan ini. Pada kegiatan pelatihan ini juga dihasilkan desain kemasan yang diharapkan dapat menarik minta konsumen untuk membeli keripik kulit mangga tersebut. 


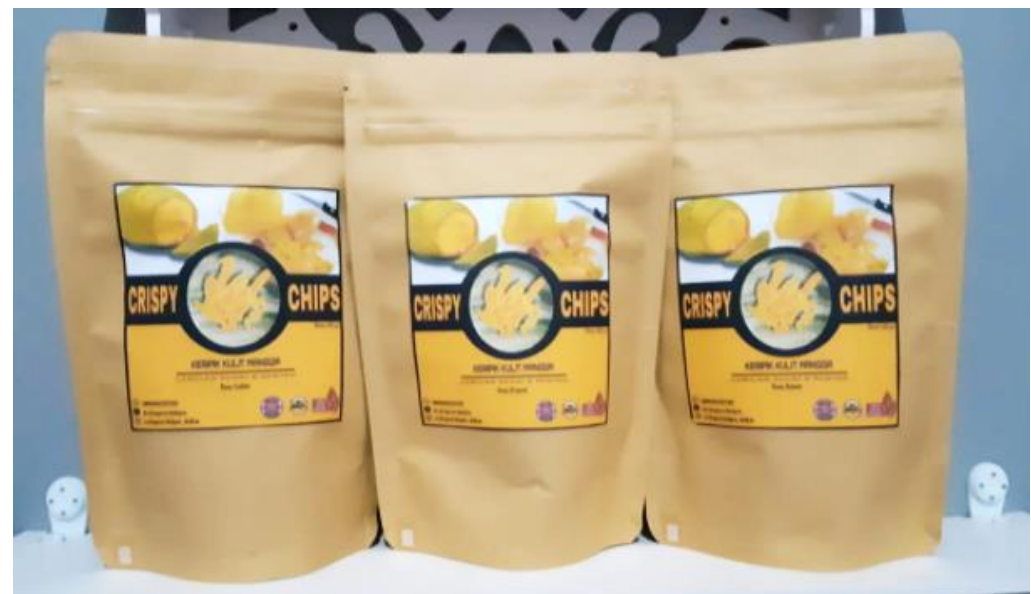

Gambar 3. Pengemasan Keripik Kulit Mangga

\section{Pelatihan Peningkatan Strategi Pemasaran Dengan Internet Marketing}

Era globalisasi saat ini telah merubah berbagai aspek kehidupan masyarakat, termasuk dalam hal penggunaan internet dan media sosial untuk kegiatan promosi dan jual beli secara online sehingga pemasaran dapat dilakukan secara luas. Oleh karena itu, tim pelaksana pengabdian kepada masyarakat juga mengadakan kegiatan pelatihan kepada peserta untuk berjualan dan memasarkan produk dengan menggunakan media sosial. Pelatihan ini dilaksanakan pada hari Minggu, 27 Desember 2020. Dalam hal ini, media sosial yang akan digunakan adalah facebook dan instagram dengan pertimbangan kedua media sosial tersebut telah banyak digunakan oleh beragam kalangan masyarakat dan memiliki fitur halaman bisnis sehingga kegiatan promosi dan penjualan dapat dilakukan dengan murah dan mudah. Selain itu kegiatan penjualan dan promosi juga dapat dilakukan melalui Whatsapp dengan cara mengunggah foto produk ke status.

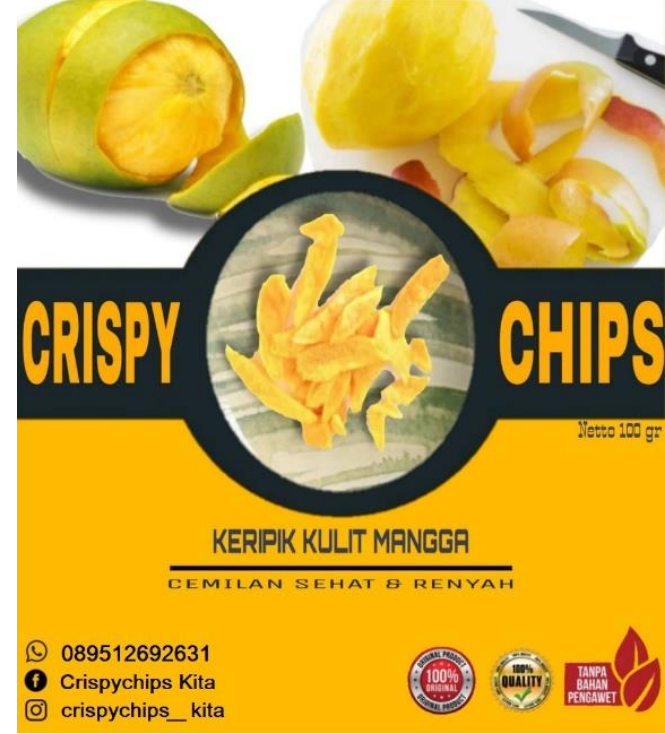

Gambar 4. Tampilan Poster untuk Promosi Penjualan

Adapun kegiatan yang dilakukan pada tahap pelatihan ini yaitu:

1. Melakukan pembuatan media sosial facebook, instagram, dan Whatsapp sebagai media promosi dan penjualan produk.

2. Melakukan pelatihan membuat konten yang menarik, promosi di media sosial, mencari target konsumen, dan bentuk pelayanan customer service online pada Instagram, facebook dan Whatsapp. 


\section{E. Kegiatan Pelatihan Manajemen Keuangan}

Pada pelaksaan pengabdian tanggal 27 Desember 2020, selain diberi pelatihan strategi pemasaran yang efektif dengan memanfaatkan media sosial, peserta juga diberi pelatihan cara mengelola keuangan dengan baik dan benar karena pada dasarnya, usaha akan berjalan dengan baik jika pemasaran dan pengelolan keuangan yang baik pula. Kegiatan ini begitu penting untuk dilaksanakan demi keberlanjutan usaha keripik kulit mangga. Pelatihan manajemen keuangan yang diberikan pada peserta yaitu cara menggunakan pembukuan sederhana dan juga menggunakan aplikasi yang sudah tersedia pada perangkat computer yaitu Microsoft Excel.

\section{KESIMPULAN DAN SARAN}

Berdasarkan hasil kegiatan Program Pengabdian Masyarakat di Kampung Bukkolan RT.02 RW.01 Desa Paowan, Kecamatan Panarukan, Kabupaten Situbondo diperoleh kesimpulan bahwa peserta mengikuti kegiatan penyuluhan dan pelatihan dengan penuh antusias. Selain itu peserta juga telah mengetahui cara pengolahan kulit mangga menjadi keripik, mengemas keripik kulit mangga dengan baik dan benar, melakukan penjualan dan pemasaran secara online, serta melakukan pembukuan dengan pembukuan secara sederhana dan dengan menggunakan Microsoft Excel. Saran untuk kedepan, para peserta dapat menambah varian rasa pada keripik kulit mangga yang dibuat dan terus mempraktikkan pelatihan yang didapat pada kegiatan pengabdian ini.

\section{UCAPAN TERIMA KASIH}

Ucapan terima kasih Tim Pengabdian Kepada Masyarakat (PKM) sampaikan kepada Lembaga Penelitian dan Pengabdian Masyarakat Universitas Muhammadiyah Jember atas pembiayaan kegiatan pengabdian ini melalui program Pengabdian kepada Masyarakat Skim Program Kemitraan Masyarakat Tahun Anggaran 2020/2021.

\section{DAFTAR PUSTAKA}

Halik, A., Yudi, A., \& Rosandi. (2019). Pengolahan Potensi Mangga Untuk Dijadikan Keripik Kulit Mangga. Jurnal Abdikarya: Jurnal Karya Pengabdian Dosen Dan Mahasisw, 3(3), 297-299.

Kim, H., Moon, J. Y., Kim, H., Lee, D. S., Cho, M., Choi, H. K., Kim, Y. S., Mosaddik, A., \& Cho, S. K. (2010). Antioxidant and Antiproliferative Activities of Mango (Mangifera indica L.) Flesh and Peel. Food Chemistry, 121(2), 429-436

Kumar, S., \& Pandey, A. K. (2013). Chemistry and Biological Activities of Flavonoids: An Overview Shashank. The Scientific World Journal, 1-16.

Mukti, G. W., Rasmikayati, E., Kusumo, R. A. B., \& Fatimah, S. (2017). Peningkatan Nilai Tambah Limbah Kulit Mangga Melalui Pelatihan Pembuatan Keripik Dan Manisan Kulit Mangga. Jurnal Pengabdian Kepada Masyarakat, 1(3), 140-144.

Saragih, B. (2004). Pembangunan Pertanian dengan Paradigma Sistem dan Usaha Agribisnsis.http://pse.litbang.pertanian.go.id/ind/pdffiles/Anjak_2004_VI_01.pdf 